\section{THE CONSTITUTIONALITY OF LOCAL OPTION LAWS.}

In an article contributed to this journal some time since, ${ }^{1}$ the writer, after reviewing the subject somewhat at length, arrived at the conclusion that the local option laws are unconstitutional. The article seems to have been suggested by the efforts that were then being made in the State of Obio, to induce the legislature of that State to enact a law of this character. The conclusion, as embodied in the writer's words, was as follows: "Whether we look at this question in the light of the overwhelming analogy furnished by the decided weight of judicial authority in this and other States, or whether we confine it to the plain text of the Constitution of Ohio, it seems difficult to reach any conclusion other than that the scheme of local option, as it is now urged upon the legislature and the public of the State, will be found radically and fundamentally defective when brought to the decisive test of judicial scrutiny." We sincerely doubt whether "the decided weight of judicial authority" is quite so "overwhelming" in its character, as the writer seems to have supposed. It certainly is not so "overwhelming," as to render it "difficult to reach any conclusion other than that the scheme" was unconstitutional. The writer has evidently over-estimated his difficulties, and mistaken the weight of authority. In the course of the article referred to, Mr. Justice Cooley is quoted to the following effect: "If the decision of this question is to depend upon the weight of judicial authority up to the present time, it must be held that there is no power to refer the adoption or rejection of a general law to the people of the State, any more than there is to refer it to any other authority. The prevailing doctrine in the courts appears to be that, except in those cases where, by the Constitution, the people have expressly reserved to themselves a power of decision, the functions of legislation cannot be exercised by them, even to the extent of accepting or rejecting a law which has been framed for their consideration."'2 There is 'no doubt of the perfect correctness of the propositions thus lajd down by the learned Chief Justice of

110 Cent. L. J. 203.

Const. Lim. p. 1 e.
Michigan, who bas been worthily styled "without doubt the foremost constitutional lawyer of the country," and whose elevation to the bench of the Supreme Court of the United States would be hailed by the profession of the whole country as a most fitting recognition of his sound learning, great abilities and perfectly spotless character. But it will not do to infer that, because the propositions above quoted are unquestionably correct, therefore, a local option law is unconstitutional. The learned justice was not referring to such laws, but to what is unquestionably a maxim of constitutional law, that the power to make laws cannot be delegated. In a subsequent part of the treatise from which the quotation was taken, occurs this passage: "We think that at this time the clear weight of authority is in support of legislation of this nature, commonly known as local option laws." 3

The difficulty of enforcing a prohibitory liquor law, has mainly consisted in the general apathy which has prevailed in reference to the subject. It is impossible to strictly enforce a law against which public opinion is arrayed. And prohibitory liquor laws have not been sustained with the heartiness and unanimity which their advocates have hoped for. This has been the atrong argument against their enactment. If it is not deemed wise to enact a general prohibitory liquor law, for the reason that it will not be enforced in the greater part of the State, as its opponents claim; yet, what reason is there against prohibiting the traffic in those portions of the State in which public opinion is so aroused against it as to demand frotection against its evils by its suppression? If the people of a municipality are in favor of the law, there is no doubt but that it can be enforced in that particular municipality; and there is no reason why they should not be allowed to protect themselves against the well-known evils to which it exposes them. For this reason, many of the States, whose legislatures have been unwilling to pass a general prohibitory law, suppressing the traffic throughout State limits, have, nevertheless, passed these local option laws, which put it within the power of the subdivisions of the State to suppress the traffic, provided a majority of the electors are in favor of so doing.

3 Ibid. 162. 
The great question is, are these laws constitutional? There is no doubt but that their constitutionality has been very seriously questioned. Neither is there any doubt but that, in numerous instances, such laws have been held unconstitutional, as involving a delegation of power. The legislature of Delaware, at an early day, enacted a law authorizing the citizens of the several counties of that State, to determine whether the retail of intoxicating liquors should be permitted within their respective territorial limits. 'The act provided for holding an election, and for the submission to the voters of the question of license or no license, declaring that it should not be lawful for any person to retail intoxicating liquors within such county thereafter, if a majority of the votes cast should be found to be against license. The court of errors and appeals, in Rice v. Foster, ${ }^{4}$ decided in 1847 , held that the law was void, as being an unconstitutional delegation of the law-making power. At about the same time, a similar question was raised as to the validity of a like statute passed by the legislature of Pennsylvania, and the courts of that State, in Parker v. Commonwealth, ${ }^{5}$ adjudged the law unconstitutional, for reasons similar to those which prevailed in Delaware. In 1855, the Supreme Court of Iowa, in Santo v. State, ${ }^{6}$ held a local option law unconstitutional. "The General Assembly cannot legally submit to the people," said the court, "the proposition whether an act should become a law or not; and the people have no power, in their primary or individual capactity, to make laws. They do this by representatives. There is no doubt of the authority of the legislature to pass an act to take effect upon a contingency. But what is a contingency in this sense and connection? It is some event independent of the will of the law-nasking power as exercised in making the law, or some event over which the legislature has not control. For instance, the embargo laws and their cessation were made to depend upon the action of foreign powers in relation to certain decrees. The will of the law-maker is not a contingency in relation to himself. It may be such in relation to another and external power, but to call it so in relation to him-

44 Harr. 479

66 Pa. St. 527.

2 (llarke, 279 self, is an abuse of language. Now, if the people are to say whether or not an act shall become a law, they become, or are put in the place of the law-maker. And here is the constitutional objection. Their will is not a contingency upon which certain things are, or are not to be done under the law; but it becomes the determining power whether such shall be the law or not." The same court, in 1857, in Geebrick $\vee$. State, ${ }^{7}$ and again in 1871 , in State v. Weir, ${ }^{8}$ made a similar ruling. The Supreme Court of Indiana, in Maize v. State, ${ }^{9}$ decided at an early day, reached a similar conclusion as to the unconstitutionality of a local option law which had been submitted to the people. The Supreme Court of Michigan, in People v. Hawley, ${ }^{10}$ was equally divided upon the question. So that it must be conceded that the early decisions upon this subject were decidedly opposed to the validity of these enactments. But the recent decisions, with the exception of $E x$ parte Wall, ${ }^{11}$ decided in 1874 , are as decidedly in favor of their validity, and leave no room for doubt but that such laws may be constitutional. This change of ruling is due somewhat to a change in the mode in which the law itself is drawn, as will be hereafter, pointed out. And it is worthy of note, that in the recent case of $E x$ parte Wall, the California court was divided in opinion,- - three of the judges holding that the law was unconstitutional, while the other two were equally as decided in favor of its constitutionality.

But in 1873, the Supreme Court of Indiana sustained the constitutionality of a law which attained the same end as the ordinary local option law, and which is so peculiar in its character as to merit attention. This statute provided that it should be unlawful to sell withous a permit from the county commissioners, and required every person desiring such permit, to file his application in writing with the auditor of the proper county, not less than twenty days before the first day of the term of any regular session of the board of county commissioners. This application had to be signed, not merely by the applicant, but also by a majority of the legal

75 Clarke, 491 833 Iowa, 134 94 Ind. 342.

103 Mich. 330

11. $48 \mathrm{Cal} .279$ 
voters living in the same ward with the applicant, if in a city, or in the town, if in an incorporated town or township. 'The court saw no objection to the act, as 'it was enacted in the usual form of enacting laws, and was declared by the legislature that it should be in force from and after its passage." 12 So the Supreme Court of Pennsylvania, which, as we have seen, adjudged a local option law void in 1847, did, in 1873, in Locke's Appeal,13 adjudge a local option law valid. This last act prohibited sale without license, and authorized the voters of a municipal district to decide at an election for or against granting license; and provided that in case the election went against license, the issuing of the license should be unlawful. In passing upon the constitutionality of this statute, the court said: "What did the legislature in this section submit to the people, and what did they not submit? This is quite as clear as any other part of the act. Each elector is to vote a ticket for license, or against license. He is allowed by the law to say, 'I am for the issuing of license,' or 'I am against the issuing of licenses;' and thus to express his judgment or opinion. But this was all he was permitted by law to do. He declared no consequences, and prescribed no rule resulting from his opinion. Nor does the majority of votes declare a consequence. 'The return of a majority is but of a mere numerical preponderance of votes, and expresses only the opinion of the greater number of electors upon the expediency or inexpediency of licenses in this ward. When this is certified by the return, the legislature, not the voters, declare it shall (or it shall not) be lawful for any license to issue for the sale of spirituous liquors.' 'Thus it is perfectly manifest this law was not made, pronounced or ratified by the people; and the majority vote is but an ascertainment of the public sentiment-the expression of a general opinion, which, as a fact, the legislature have made the contingency on which the law shall operate. When the law came from the halls of legislation, it came a perfect law; mandatory in all its parts, prohibiting in this ward the sale of intoxicating liquors without license; commanding an election to be held every third year to ascertain the expediency

32 Groesch v. State, 42 Ind. 557. of issuing licenses, and when the fact of expediency or inexpediency shall have been returned, commanding that licenses shall issue or shall not issue."

The Supreme Court of Iowa, which, as we have seen, had held a loaal opinion law unconstitutional, upheld in Dalby v. Wolf, ${ }^{14}$ decided in 1862 , this same distinction, and sustained the constitutionality of a law authorizing the people of the several counties to decide by a majority vote whether swine and sheep should be restrained from running at large: The court said that counsel utterly misapprehended the scope and spirit of the decisions in Iowa and other States, which held that the legislature could not refer to the people the question, whether a particular act should become a law, and declared that in all the cases which bad been referred to, the question submitted had been, whether or not a proposed law should become operative. For instance, in one law it was provided as follows: "The electors shall determine by ballot at the anmual election to be beld in November next, whether this act shall or shall not become a law," and if a majority voted against it, then it was to be void, but if a majority favored it, then it was to take effect from a day named. As the law in question was not obnoxious to this objection, it was sustained. "The popular will is expressed under and by virtue of a law that is in force and effect, and the people neither make nor repeal it. They only determine whether a certain thing shall be done under the law, and not whether said law shall take effect. The law had full and absolute vitality when it passed from the hands of the legislature."13

In 1872 . the constitutionality of a local option law was sustained in New Jersey, in State v. Court of Common Pleas. ${ }^{15}$ This law provided that it should be liwful for persons duly qualified to determine by ballot whether license should be granted. That if a majority of the votes cast were for no license, it should not thereafter be lawful to grant any such license until otherwise decided by a contrary vote at some subsequent town meeting; that from and after the passage of the act, it should not be lawful for any person within said township, without a license, to sell

\section{$1372 \mathrm{~Pa}$, St. 491. \\ 1414 Iowa, 228.}

7536 N. J. Law, 72. 
intoxicating liquors, etc. The court conceded that the law could not be sustained if it involved a delegation of the law-making power, and aid: "The will of the legislature must be expressed in the form of a law by their own acts. If it is left to the contingency of a popular vote to pronounce whether it shall take effect, it is not the will of the law-makers, but the voice of their constituents which molds the rule of action. * * * The test will be whether this enactment, when it passed from the hands of the law-giver, had taken the form of a complete law. It denounces as a misdemeanor the selling of liquor without license; so far it is positive and free from any contingency. It left to the popular vote to determine, not whether it should be lawful to sell without license, but whether the contingency should arise under which license might be granted. **** The legislature has pronounced what the law shall be, and it can not be, and is not, abrogaterl, changed or altered by the popular expression."

In 1875 the Supreme Court of Maryland also sustained the constitutionality of a local option law, in Fell v. State. ${ }^{16}$ The act provided : 1 . For an election to be held on a certain day, at which the roters of the several election districts, in the counties named in the act, should cast their ballots "for the sale of spirituous or fermented liquors," or "against the sale" of such liquors. 2. That if it should be found that a majority of the votes in any district had been cast against the sale of such liquors, then it should not be Iawful for any person to sell such liquors in said district. 3. A penalty was prescribed for the violation of the act. 4 . It was provided that the act should take effect immediately after it should have been determined by a majority of the people in any such district that such sale should not be made. "Now, what has been delegated to the voters," asked the court, "by this act of assembly? Certainly not the power to make the law, or to repeal existing laws. They are called on by the first section simply to express, by their ballots, their opinion or sentiments as to the subject-matter to which the law relates. They declare no consequences, prescribe no penalties, and exercise no legislative functions. The consequences are de-

$1642 \mathrm{Md} .71$ clared in the law, and are exclusively the result of the legislative will. The act of the assembly is a perfect and complete law, as it left the halls of legislation and was approved by the governor; but by its terms it was made to go into operation in any district, upon the contingency of a majority of the legal voters within the district being ascertained to be in favor of the prohibition contained in the second section." The law was thereupon upheld. In this same year the Supreme Court of Connecticut sustained one of these laws, in State v. Wilcox. ${ }^{17}$ This law prohibited the sale of liquors without a license, and authorized the county commissioners to grant licenses upon the reccmmendations of the selectmen of the town. But the law also provided that any town might, at its annual meeting, by ballot prohibit the selectmen from making such recommendations. The court thought that such a law did not involve a delegation of legislative power to the people, to the county commissioners, or to the selectmen, but that it was a perfect and complete enactment as it came from the hands of the law-making power. "Licenses may be granted by the county commissioners to suitable persons, if recommended by a majority of the selectmen, and the towns may instruct their selectmen not to recommend any persons. But these are not legislative powers. 'They are police regula. tions, quite fit and proper to be exercised by municipalities, county commissioners, or boards of selectmen, for the protection of the morals and health, and the promotion of the prosperity of their localities."

And this brings us to the consideration of another reason which has of late been assigned to sustain the constitutionality of these local option laws. It is conceded that the legislature can empower municipal corporations to regulate or prohibit the traffic in intoxicating liquors, as it shall deem for the best interests of their respective municipalities. If the common council of a city, or the supervisors of a county, can be invested with this discretionary power of establishing suitable police regulations, why not empower the people themselves to determine the question of license or no license? A trust can not be delegated to one body rather than another;

1742 Conn. 364 . 
and if it is not an unconstitutional delegation of legislative power, an abrogation of the trust reposed in the law-making power, to enact that a common council of a city may make proper police regulations in reference to this subject, how can it be unconstitutional to invest the people themselves with this power? If the one does not involve an abrogation of the trust, it is submitted that the other does not. 'Ihis is the view taken of this question by the Supreme Judicial Court of Massachusetts in Commonwealth v. Bennett, ${ }^{18}$ decided in 1871 . In this case the law authorized the inhabitants of any city or town at any annual election, to vote for or.against the sale of spirituous or intoxicating liquors, and provided that, in case the vote was against such sale, then the sale should be prohibited in such city or town. Counsel urged upon the court the unconstitutionality of the act, upon the theory that it involved a delegation of power. The answer of the court was: "We can wee no ground for such a position." "It is equally within the power" of the legislature to authorize a town by vote of the inhabitants, or a city by vote of the city council, to determine whether the sale of particular kinds of liquors within its limits shall be permitted or prohibited." The court thought that although this subject was not embraced within the ordinary power to make by-laws and ordinances, it nevertheless fell within that class of police regulations which might properly be entrusted to municipal authority by express legislative enactment. This case has been subsequently followed by the same court in Commonwealth v. Dean. ${ }^{19}$

The same doctrine has been rerently announced by the Supreme Court of Minnesota, in State v. Cooke. ${ }^{20}$ The legislature of that State had passed an act providing that the legal voters of Rochester should have the right to vote upon and determine for themselves the question, whether license for the sale of intoxicating liquors within that mu. nicipality should be granted or not. The power to make such a prohibition had formerly been vested in the common council. 'The court, in sustaining the constitutionality of the act, said: "When the legislature confers any power upon a municipal corporation,

18108 Mass. 27.

19110 Mass. 357.

2024 Minn. 247. it may prescribe by whom the power shall be exercised, by a particular officer or set of offleers, or by the electors at large; and the removal of the power in question from the council to the legal voters was unquestionably valid."

The conclusion is irresistible, that a local option law is by no means an unconstitutional. measure; that the late decisions must be regarded as having definitely decided the question, that such laws are to be upheld by the courts. To our mind the reasoning of the Massachusetts and Minnesota crses is highly satisfactory, and seems conclusive of the whole matter. The same theory, too, is advanced in the case cited from New Jersey, and we have no doubt, will commend itself to the judgment of courts, as the question may arise hereafter.

Henry Wade Rogers.

\section{THE NATURE AND EFFEC'I OF A QUIT- CLALM DEED.}

'l'he character and effect given to a deed of release and quit-claim in this country, are peculiarly American. In England, a deed of release, under general principles of law, can never operate as a conveyance in a technical sense, unless the party taking such deed is in possession of the land, and then the deed merely operates to enlarge the estate, whatever it may be. It could never operate as an enlargement of the estate, unless the releasee had an estate of some kind to be enlarged,such as possession or some other interest or estate in the land which qualified him for receiving or availing himself of the rights or benefits relinquished. Burton Real Prop. 15; Shep. Touch. 320; Kerr v. Freeman, 33 Miss. 292; Rowe v. Beckett, 30 Ind. 162; Branham v. Mayor, 24 Cal. 606 ; Bennett v. Irwin, 3 Johns. 363 . There, in order to give effect to the deed of release as a conveyance, it is first necessary to execute a lease, (or bargain and sale for a limited period), which, by force of the statute of uses, puts the lessee or bargainee in possession; and being thus in possession, although by a mere fiction, the release operating by way of enlargement of the estate, is effectual to transfer the entire title. In Hall $v$. Ashby, (9 Ohio, 96), the court say: "So artificial a machinery, for the purpose of effecting an objeet so very simple, has never been considered necessary in this State." It is true that in England, as well as in this count:y, courts have gone very far in modifying the rules of conveyance, both those of the conmon law and those which have their effect from the statute of uses, so as to give effect and operation to the deeds of parties, rather according to the manifest intent, than according 